\begin{tabular}{l|l} 
Potaice & e-ISSN: 2655-9404 \\
Vol. 01 No. 2, Oktober 2018 & DOI: 10.20473/ntr.v1i2.10954 \\
\hline
\end{tabular}

Article history: Submitted 3 October 2018; Accepted 10 October 2018; Available online 15 October 2018.

\title{
Tanggung Jawab Konsorsium Asuransi Penyingkiran Kerangka Kapal
}

\author{
Nurhuda Sulaeman dan Agus Widyantoro \\ sayahuda.nh@gmail.com \\ Universitas Airlangga
}

\begin{abstract}
The growths of technology make the privacy of personal information become an important issue in Wreck removal insurance consortium is the cooperation agreement of a leader and members which liable as insurer of wreck removal including pollution responsibility. The consortium was formed to facilitate ship owners to undertake regulation from government while encouraging escalation of domestic insurance capacity to meet domestic insurance coverage needs. Furthermore, OJK has plans to develop Indonesia Protetion and Indemnity policy. This research is the type of normative legal research using a statute approach, conceptual approach, and case approach. The consortium is joint form of business that has been recognized in Indonesia. Althouht, there are characters resemblance with civil partnership, but not all elements of civil parnership are attached to the consortium. Leader and members fulfill joint coverage and manage the risks undertaken in accordance with the agreed quota share in the contract. The member companies of consortium will indemnify the insured againts obligations, costs and legitimate expenses in accordance with the insurance class that occur in connection with the operation of the ship owned by the insured arising from events that occur during the period of coverage.
\end{abstract}

Keyword: Consortium; Insurance; Wreck; Ship.

\begin{abstract}
Abstrak
Konsorsium asuransi penyingkiran kerangka kapal merupakan perjanjian kerja sama yang terdiri dari ketua dan anggota yang berkedudukan sebagai Penanggung Asuransi Penyingkiran Kerangka Kapal termasuk tanggung jawab polusi. Konsorsium dibentuk untuk memudahkan pemilik kapal melaksanakan aturan dari pemerintah sekaligus mendorong peningkatan kapasitas asuransi dalam negeri guna memenuhi kebutuhan pertanggungan asuransi dalam negeri. Di sisi lain, OJK memiliki rencana untuk mengembangkan polis Protection \& Indemnity Indonesia. Penelitian ini adalah tipe penelitian hukum normatif yakni dengan menggunakan pendekatan perundang-undangan (statute approach), pendekatan konseptual (conceptual approach), dan pendekatan kasus (case approach). Konsorsium merupakan salah satu bentuk kerja sama bisnis yang telah diakui eksistensinya di Indonesia. Walaupun ada kesamaan karakter dengan persekutuan perdata, namun tidak seluruh unsur dari persekutuan perdata melekat padanya. Ketua dan anggota bekerja sama untuk melakukan pertanggungan dan para pihak bersama-sama mengelola risiko yang menjadi tanggungan bersama sesuai kuota share yang disepakati di dalam kontrak. Perusahaan anggota konsorsium akan mengganti kerugian Tertanggung terhadap kewajiban-kewajiban, biaya-biaya, dan pengeluaran-pengeluaran yang sah sesuai kelas asuransi yang terjadi sehubungan dengan operasi kapal milik Tertanggung yang timbul dari peristiwa-peristiwa yang terjadi selama periode pertanggungan.

Kata Kunci: Konsorsium; Asuransi; Kerangka; Kapal.
\end{abstract}

\section{Pendahuluan}

Di bidang pengangkutan laut, pengangkut atau pemilik kapal dihadapkan 
pada risiko dari dua sisi, yaitu risiko sebagai kapal (as a ship) dan risiko sebagai alat pengangkut (as a carrier). Ruang lingkup asuransi pengangkutan laut sangat luas, sehingga tidak semua risiko mampu dilindungi dalam satu produk asuransi. Untuk menghadapi risiko yang tidak ditanggung oleh penanggung, para pengusaha kapal membentuk perkumpulan sesama mereka yang dikenal dengan sebutan "Protection and Indemnity Club" atau disingkat dengan P\&I $C l u b$, yang bertujuan untuk menanggung kerugian yang kemungkinan dialami oleh anggotanya, sepanjang kerugian tersebut tidak mendapat ganti rugi dari penanggung (underwriters). Perkumpulan ini memberikan pertanggungan kepada para anggota dari dua segi, yakni perlindungan (protection) dan segi jaminan (indemnity). ${ }^{1}$ Protection and Indemnity (P\&I) ini kemudian dikenal sebagai salah satu produk asuransi kapal laut.

Meskipun jenis asuransi P\&I sudah cukup lama beroperasi, ternyata di Indonesia masih sedikit pelaku bisnis perkapalan nasional yang mengasuransikan kapalnya dengan asuransi P\&I. Hampir semua kapal yang berlayar secara domestik tidak memperdulikan penutupan asuransi P\&I, kecuali kapal-kapal samudera yang melayani perniagaan internasional dan kapal-kapal pengangkut peti kemas yang berlayar secara reguler ke negara-negara tetangga seperti Malaysia, Singapura dan Thailand, mereka biasanya men-cover kapalnya dengan asuransi P\&I. ${ }^{2}$

Salah satu faktor yang mempengaruhi keselamatan dan keamanan berlayar adalah lalu lintas perairan yang bersih. Pemerintah bertanggung jawab atas alur pelayaran yang selamat dan aman bagi kapal yang berlayar di wilayah perairan laut Indonesia. Beberapa kasus tenggelamnya kapal disebabkan bertubrukan dengan kerangka kapal yang tidak disingkirkan dari alur pelayaran, seperti kasus kapal KM Kumala Endah yang tenggelam di Belawan Sumatera Utara pada Maret 2015 sebagaimana tertuang dalam putusan Mahkamah Pelayaran Nomor HK. 210/02/I/MP.16.

\footnotetext{
1 Sentosa Sembiring, Hukum Asuransi (Nuansa Aulia 2014).[92-93].

2 Sugiyanto, Hukum Asuransi Maritim Protetion \& Indemnity Insurance (Salemba Humanika 2009).[6-7].
} 
Peristiwa kejadian tenggelamnya KM Kumala Endah tidak terlepas dari rangkaian sebab akibat adanya bahaya navigasi di bawah air laut (kerangka kapal) dan belum tertera pada peta laut sehingga KM Kumala Endah bertubrukan dengan benda tersebut. Keberadaan kerangka tersebut telah lama dan telah menelam beberapa korban sebelumnya, namun sampai dengan kejadian tenggelamnya KM Kumala Endah keadaan kerangka tersebut belum tertera dalam peta laut dan belum ada tanda pengenalnya secara permanen. Kasus tersebut tidak hanya menimbulkan korban jiwa namun juga kerugian materil bagi pihak yang menggunakan jasa angkutan kapal tersebut sebagaimana tertuang dalam putusan Nomor 321/Pdt. G/2016/PN Mdn.

Untuk menjamin keselamatan dan keamanan pelayaran di seluruh perairan Indonesia, Pemerintah dalam hal ini Kementerian Perhubungan Laut Direktorat Jenderal Perhubungan Laut mewajibkan pemilik kapal yang memiliki kapal motor dengan ukuran minimal 35 GT (tigapuluh lima Gross Tonnage) untuk mengasuransikan kapalnya dengan Asuransi Penyingkiran Kerangka Kapal dan/ atau Perlindungan Ganti Rugi. Hal ini sebagaimana disampaikan melalui Surat Edaran Menteri Perhubungan Nomor AL. 801/1/2 Phb 2014 tentang Kewajiban Mengasuransikan Kapal dengan Asuransi Penyingkiran Kerangka Kapal dan/atau Perlindungan Ganti Rugi.

Kewajiban penyingkiran kerangka kapal sebelumnya sudah diatur di dalam Undang-Undang Nomor 17 Tahun 2008 tentang Pelayaran (selanjutnya disebut UU Pelayaran). Kapal yang mengalami kecelakaan dan tenggelam di perairan dapat membahayakan sistem navigasi atau dapat menubruk kapal lainnya yang sedang berlayar sehingga harus segera dilakukan pengangkatan dan penyingkiran kerangka kapal sebagaimana diatur di dalam Pasal 203 UU Pelayaran, pemilik kapal berkewajiban untuk menyingkirkan kerangka kapal dan/atau muatannya yang mengganggu keselamatan dan keamanan pelayaran paling lama 180 (seratus delapanpuluh) hari sejak kapal tenggelam, sehingga untuk menjamin kewajibannya tersebut pemilik kapal wajib mengasuransikan kapalnya. Supaya memudahkan bagi pemilik kapal melaksanakan aturan di atas, OJK mengusulkan adanya produk 
asuransi penyingkiran kerangka kapal yang dikelola dalam bentuk konsorsium. Konsorsium ini terdiri dari beberapa perusahaan asuransi nasional yang memberikan jaminan perlindungan bagi pemilik kapal terkait kewajiban pemilik kapal apabila kapalnya tenggelam.

Terkait dengan produk asuransi yang dilakukan dalam bentuk konsorsium belum diatur di dalam Undang-Undang Nomor 40 Tahun 2014 tentang Perasuransian (selanjutnya disebut UU Perasuransian), namun Pasal 18 UU Perasuransian dapat menjadi landasannya bahwa perusahaan perasuransian dapat melakukan kerja sama dengan pihak lainnya untuk meperluas bisnis atau untuk melaksanakan sebagian fungsi dalam penyelenggaraan usahanya. Mengingat bahwa dalam pembentukan konsorsium asuransi penyingkiran kerangka kapal melibatkan sejumlah perusahaan asuransi yang berkedudukan sebagai Penanggung, sehingga perlu dianalisis lebih lanjut mengenai karakteristik konsorsium dan tanggung jawab masing-masing pihak perusahaan asuransi yang tergabung di dalam konsorsium.

Penelitian ini adalah penelitian hukum normatif yang menggunakan pendekatan perundang-undangan (statute approach) yaitu dengan mempelajari semua peraturan-peraturan yang saling berkaitan dengan isu hukum yang sedang dihadapi, pendekatan konseptual (conceptual approach) yaitu dilakukan dengan cara mempelajari sejumlah pandangan dan doktrin yang sedang berkembang di dalam ilmu hukum, dan pendekatan kasus (case aprproah) yaitu dilakukan dengan cara menganalisis kasus-kasus yang telah menjadi putusan pengadilan yang ada kaitannya dengan isu hukum yang sedang dihadapi. ${ }^{3}$

\section{Karakteristik Konsorsium Asuransi Penyingkiran Kerangka Kapal}

Konsorsium asuransi penyingkiran kerangka kapal adalah kumpulan sejumlah perusahaan asuransi kerugian yang dibentuk berdasarkan perjanjian kerja sama antara PT Tugu Pratama Indonesia dengan perusahaan asuransi anggota konsorsium yang dituangkan dalam Perjanjian Kerja Sama Nomor 022/PK/CGS-

\footnotetext{
3 Peter Mahmud Marzuki, Penelitian Hukum (Kencana 2011).[133-136]
} 
TPI/III/2015 tanggal 17 Maret 2015 tentang Konsorsium Asuransi Penyingkiran Kerangka Kapal (Wreck Removal Insurance) dan Perjanjian Kerja Sama Nomor 083/PK/CGS-TPI/VI/2015 tanggal 01 Maret 2016 tentang Konsorsium Asuransi Penyingkiran Kerangka Kapal Termasuk Tanggung Jawab Polusi. Konsorsium yang tidak lain adalah gabungan beberapa perusahaan yang disatukan dalam ikatan perjanjian. Bentuk konsorsium asuransi penyingkiran kerangka kapal bukanlah badan hukum melainkan berupa perjanjian kerja sama antara beberapa perusahaan asuransi untuk melakukan pertanggungan bersama.

Dalam dunia bisnis, perjanjian kerja sama seringkali dilakukan oleh pelaku usaha dalam rangka membuka atau mengembangkan usahanya. Perjanjian tersebut muncul sebagai akibat perkembangan dan kebutuhan masyarakat. ${ }^{4}$

Beberapa penulis berpendapat bahwa konsorsium juga termasuk ke dalam persekutuan perdata, akan tetapi apabila melihat pada praktiknya konsorsium bukanlah sepenuhnya merupakan persekutuan perdata meskipun ada kesamaan karakter dengan persekutuan perdata. Tidak seluruh unsur dari persekutuan perdata melekat padanya, sebab konsorsium merupakan perjanjian kerja sama yang tidak berakhir apabila salah satu anggotanya keluar atau meninggal melainkan berakhirnya konsorsium didasarkan pada kesepakatan para anggotanya atau ketika tujuan proyek konsorsium tersebut telah tercapai, sedangkan ciri khusus dari persekutuan perdata adalah persekutuan perdata akan berakhir apabila salah seorang sekutunya meninggal atau di bawah pengampuan, hal ini sebagaimana diatur di dalam Pasal 1646 KUHPerdata.

Perkembangan industri perasuransian saat ini cukup pesat sehingga mendorong perusahaan untuk mengembangkan produk asuransi yang semakin beragam dan kompleks. Selain itu, saat ini produk asuransi yang merupakan bagian dari produk jasa keuangan mulai memiliki karakteristik yang hampir sama dengan produk jasa keuangan lainnya seperti bank dan pasar modal. Salah satu perkembangan bisnis persuransian yaitu produk asuransi bersama, sebagaimana diatur di dalam Pasal 5

\footnotetext{
4 Irawan Soerodjo, Hukum Perjanjian dan Pertanahan Perjanjian Build, Operate dan Transfer (BOT) atas Tanah, Pengaturan, Karakteristik dan Praktik (Laksbang Pressindo 2016).[46-47].
} 
Ayat 1 Peraturan Otoritas Jasa Keuangan Nomor 23/POJK.05/2015 tentang Produk Asuransi dan Pemasaran Produk Asuransi bahwa produk asuransi bersama dirancang untuk dipasarkan dan ditanggung atau dikelola risikonya oleh 2 (dua) atau lebih perusahaan asuransi melalui mekanisme kerja sama. Lebih lanjut lagi diatur pada Pasal 6 POJK Nomor 23/2015 bahwa produk asuransi bersama harus dituangkan dalam suatu perjanjian tertulis yang memuat susunan keanggotaan, termasuk perusahaan yang menjadi Ketua (Leader) yang akan mengkoordinir kegiatan pemasaran produk asuransi bersama dimaksud; tugas ketua; pembagian risiko untuk masing-masing perusahaan yang tergabung dalam pemasaran produk asuransi bersama sesuai dengan ruang lingkup usaha masing-masing perusahaan; tata cara pembayaran premi atau kontribusi oleh pemegang polis; prosedur underwriting, prosedur penerimaan, dan penerusan premi atau kontribusi, serta prosedur penyelesaian dan pembayaran klaim; dan prosedur penyelesaian perselisihan antara Perusahaan yang tergabung dalam pemasaran Produk Asuransi Bersama.

Berdasarkan ketentuan di atas dapat diketahu bahwa bentuk kerja sama yang dimaksud adalah konsorsium, sebagaimana juga disebutkan pada penjelasan Pasal 5 POJK di atas bahwa contoh Produk Asuransi Bersama adalah produk konsorsium asuransi Tenaga Kerja Indonesia (TKI). Jadi pemerintah telah mengakui bentuk konsorsium sebagai salah satu mekanisme kerja sama perusahaan perasuransian di dalam pengelolaan produk asuransi.

Tujuan dibentuknya konsorsium asuransi penyingkiran kerangka kapal adalah sebagai upaya mendukung program pemerintah yakni Kementerian Perhubungan Direktorat Jenderal Perhubungan Laut untuk mewujudkan lingkungan perairan yang bersih serta menjamin keselamatan dan keamanan pelayaran di seluruh perairan Indonesia. Sebagaimana diatur di dalam Pasal 203 UU Pelayaran, pemilik kapal berkewajiban untuk menyingkirkan kerangka kapal dan muatannya yang mengganggu keselamatan dan keamanan pelayaran maksimal 180 (seratus delapanpuluh) hari sejak kapal tenggelam. Untuk menjamin kewajiban pemilik kapal tersebut, pemilik kapal dibebankan kewajiban untuk mengasuransikan kapalnya. Apabila pemilik kapal tidak melaksanakan kewajibannya tersebut, maka pemerintah yang berkewajian melaksanakannya dengan 
biaya dibebankan kepada pemilik kapal, termasuk penggantian kerugian kepada pihak yang dirugikan jika kerangka kapal menyebabkan terjadinya kecelakaan pelayaran.

Selain bertujuan untuk memudahkan pelaksanaan aturan di atas, pemerintah juga bertujuan untuk mendorong peningkatan kapasitas asuransi dalam negeri guna memenuhi kebutuhan pertanggungan asuransi dalam negeri. Di sisi lain, OJK memiliki rencana untuk mengembangkan polis Protection \& Indemnity Indonesia agar diakui secara internasional. Namun demikian, sebagai langkah awal, ketersediaan produk asuransi penyingkiran kerangka kapal yang sesungguhnya merupakan bagian dari produk Protection \& Indemnity untuk sementara waktu menjadi prioritas. ${ }^{5}$

Meskipun konsorsium ini dibentuk dalam rangka mendukung program pemerintah, namun pihak pemerintah tidak ikut andil di dalam pengelolaan konsorsium asuransi tersebut karena yang mengelola adalah konsorsium itu sendiri tapi tetap dalam pengawasan pemerintah, dalam hal ini OJK. OJK juga menyatakan bahwa tujuan pembentukan konsorsium ini dimaksudkan agar ada kesamaan dalam prosedur akseptasi dan pelayanan klaim. Selain itu, konsorsium juga mempermudah OJK dalam melakukan pengawasan. Konsorsium memiliki kapasitas yang lebih besar dan dapat mengakumulasi risiko secara bersama-sama. Melalui konsorsium, maka posisi tawar menjadi lebih kuat untuk menghadapi reasuradur. ${ }^{6}$

Pemilik kapal sebagai Tertanggung merupakan pihak yang melakukan kontrak atau dikenal sebagai pemegang polis. Pihak yang akan mendapatkan ganti kerugian dari perusahaan asuransi adalah pemilik kapal dan pihak ketiga yaitu Kementerian Perhubungan Direktorat Jenderal Perhubungan Laut. Objek asuransi dalam produk asuransi ini adalah pemberian jasa pelayanan operasional dalam upaya pembersihan kerangka kapal yang tenggelam termasuk tanggung jawab polusi yang merupakan tanggung jawab hukum Tertanggung kepada pihak ketiga. ${ }^{7}$

\footnotetext{
5 Dumoly F Pardede, 'Pointers Welcome Speech Sosialisasi Produk Asuransi Penyingkiran Kerangka Kapal', (Otoritas Jasa Keuangan 2015).

6 Ibid.

7 PT Tugu Pratama Indonesia Tbk., 'Lampiran Prosedur Penutupan Konsorsium Asuransi Penyingkiran Kerangka Kapal Termasuk Tanggung Jawab Polusi' (Wreck Removal Insurance Consortium 2018) <http://www.wriconsortium.com> diakses tanggal 17 Mei 2018.
} 
Apabila diperhatikan rumusan objek asuransi sebagaimana diatur dalam UU Perasuransian, terlihat bahwa salah satu objek asuransi adalah tanggung jawab hukum. Tanggung jawab hukum yang dimaksud di sini adalah terkait dengan kewajiban seseorang untuk memberikan ganti rugi, karena perbuatan yang dilakukan oleh orang tersebut mengakibatkan kerugian bagi yang lain. Terhadap tanggung jawab hukum orang yang bersangkutan dapat diasuransikan. Untuk jenis asuransi ini lebih dikenal dengan asuransi tanggung gugat (liability insurance). ${ }^{8}$

\section{Tanggung Jawab Anggota Konsorsium Asuransi Dalam Penyelesaian Klaim Asuransi Penyingkiran Kerangka Kapal}

Bentuk kerja sama konsorsium adalah bentuk kontraktual yang berdasarkan kontrak/perjanjian. Artinya berdasarkan apa yang telah diperjanjikan di dalam kontrak konsorsium, termasuk di dalamnya mengenai kontribusi masing-masing anggota dan tanggung jawab pertanggungan dibagi berdasarkan persentase kontribusi sesuai kontrak. Perusahaan asuransi biasanya membentuk konsorsium untuk melakukan pertanggungan bersama sebagai upaya untuk menanggulangi risiko yang terlalu besar dan sekaligus memperluas pasar dari produk suatu jenis asuransi tertentu. ${ }^{9}$

Permodalan di dalam konsorsium asuransi disebut share atau besaran jatah bagian. Ketika konsorsium menerima Premi sebesar 1 (satu) Miliyar, maka akan dibagi berdasarkan kuota share masing-masing yang biasanya dibuat dalam bentuk persentase. Otomatis yang memegang kuota share terbesar itulah yang akan menjadi Leader dari konsorsium tersebut. Begitu pun nanti bila terjadi klaim dari Tertanggung, pembagian tanggung jawab juga berdasarkan kuota share tersebut. Demikian pula dengan keuntungan yang nantinya diperoleh dari bisnis tersebut akan dibagi menurut besaran atau kuota share yang telah disepakati bersama. ${ }^{10}$

Besar share pertanggungan dan premi asuransi penyingkiran kerangka kapal termasuk tanggung jawab polusi (wreck removal insurance including pollution liability) masing-msing Penanggung di dalam konsorsium yang disepakati oleh

\footnotetext{
8 Sentosa Sembiring, Op. Cit. 85.

9 Wawancara dengan Ahli Asuransi PT Asuransi Bumiputera, Mei 2018.

10 ibid.
} 
para pihak sebagaimana tertuang di dalam perjanjian sebagai berikut: ${ }^{11}$

Tabel 2. Besaran Bagian (Share) Pertanggungan

\begin{tabular}{lc}
\hline \multicolumn{1}{c}{ Anggota Konsorsium } & Besaran (Share) \\
& Pertanggungan \\
\hline PT Tugu Pratama Indonesia & $14.50 \%$ \\
PT Asuransi Jasa Indoenesia & $7.50 \%$ \\
PT Asuransi Adira Dinamika & $7.50 \%$ \\
PT Asuransi Purna Arthanugraha & $7.50 \%$ \\
PT Asuransi Central Asia & $7.50 \%$ \\
PT Asuransi Sinar Mas & $7.00 \%$ \\
\hline PT Asuransi QBE Pool Indonesia & $6.50 \%$ \\
PT Asuransi Jasa Raharja Putera & $6.00 \%$ \\
PT Asuransi Wahana Tata & $5.00 \%$ \\
PT Asuransi Mega Pratama & $5.00 \%$ \\
PT Asuransi Astra Buana & $3.50 \%$ \\
PT Asuransi Bringin Sejahtera Artamakmur & $3.50 \%$ \\
PT Asuransi ASEI Indoensia & $3.50 \%$ \\
PT Asuransi Tripakarta & $3.50 \%$ \\
PT Asuransi Multi Artha Guna & $3.00 \%$ \\
PT Asuransi Binagriya Upakarta & $3.00 \%$ \\
PT Asuransi Kredit Indonesia & $3.00 \%$ \\
\hline PT Asuransi Umum Bumiputera Muda 1967 & $3.00 \%$ \\
\hline
\end{tabular}

Untuk bergabung di dalam konsorsium, perusahaan asuransi perlu menyetorkan sejumlah modal yang kemudian dikelola bersama dengan modal yang terkumpul dari anggota konsorsium lain dan dipakai untuk mengelola bisnis asuransi. Terkhusus untuk konsorsium asuransi penyingkiran kerangka kapal, para pihak yang tergabung adalah perusahaan asuransi yang sama-sama mengelola bisnis asuransi kerugian dan mempunyai minat yang sama untuk mengaksep risiko wreck removal (penyingkiran kerangka kapal). ${ }^{12}$

Para anggota yang tergabung di dalam konsorsium tidaklah ditunjuk atau ditentukan oleh pihak Pemerintah maupun pihak Leader dari konsorsium, pada prinsipnya semua perusahaan yang tertarik untuk mengelola bisnis asuransi

${ }^{11}$ PT Asuransi Tugu Pratama Indonesia Tbk., 'Wording Policy 2017 Konsorsium Asuransi Penyingkiran Kerangka Kapal Termasuk Tanggung Jawab Polusi’, (Wreck Removal Insurance Consortium 2018) <https:// http://www.wriconsortium.com/> diakses tanggal 17 April 2018.

${ }^{12}$ Wawancara dengan Ahli Asuransi Bumiputera, Mei 2018. 
penyingkiran kapal bisa bergabung dan memberikan kontribusi (memberikan modal) untuk bersama-sama mengelola bisnis asuransi penyingkiran kerangka kapal dalam bentuk konsorsium. ${ }^{13}$

Keuntungan bagi perusahaan yang bergabung di dalam konsorsium ini, di dalam prinsip asuransi dikenal adanya suatu ketidakpastian (uncertainty) dan dalam mengelola bisnis baru seperti asuransi penyingkiran kapal ini juga berlaku prinsip tersebut, alhasil perusahaan asuransi dibayangi kerugian yang cukup besar apabila mengalami suatu hal yang tidak terduga. Dengan bergabung di konsorsium, kerugian yang dialami perusahaan asuransi bisa dikontrol ke dalam satuan persentase tertentu sesuai kontribusi yang diambil dalam konsorsium, yang tadinya bisa saja loss 100\% (seratus persen) bisa berkurang ke 10\% (sepuluh persen) atau 20\% (duapuluh persen) saja, sesuai dengan kontribusi yang diambilnya dalam konsorsium. Dalam kata lain juga bisa memberikan rasa aman dan percaya diri pada perusahaan asuransi dalam mengelola bisnis baru tersebut. Pun begitu apabila setelah dikelola ternyata profil bisnis ini menguntungkan, maka perusahaan asuransi yang tergabung dalam konsorsium juga memperoleh keuntungan finansial yang sebanding dengan kontribusinya. ${ }^{14}$

Berbicara mengenai pengurusan di dalam konsorsium asuransi yakni mengenai pengurusan tugas dan kewajiban terkait pertanggungan terhadap produk asuransi penyingkiran kerangka kapal oleh pihak Perusahaan Asuransi yang bergabung menjadi anggota di dalam konsorsium. Tugas dan kewajiban dalam kerja sama ini merupakan tanggung jawab antara para pihak atau anggota konsorsium dalam pelaksanaan pertanggungan. Adapun tugas dan kewajiban yang dimaksud yaitu: ${ }^{15}$

PT Tugu Pratama Indonesia berkedudukan sebagai Pimpinan (Leader) memiliki besaran (share) pertanggungan terbesar sekaligus sebagai operator bagian terbesar dari risiko yang dikelola. Tugas dan kewajiban Leader adalah bertanggung jawab atas terwujudnya kontrak pelaksanaan pekerjaan dimaksud obyek pengikatan perjanjian ini. Pimpinan (Leader) bertugas mengkoordinir seluruh anggota dalam
${ }^{13}$ ibid.
14 ibid.
15 ibid. 
melakukan management risiko. Pimpinan (Leader) memiliki kewenangan untuk mewakili konsorsium di hadapan pihak ketiga dan pengadilan.

Tugas dan kewajiban seluruh anggota bersama dengan Leader adalah bertanggung jawab dalam penyelenggaraan usaha asuransi /coverage penyingkiran kerangka kapal, sesuai dengan besaran (share) secara proporsional. Semua anggota berwenang untuk menawarkan dan memasarkan produk asuransi penyingkiran kerangka kapal sesuai dengan kebutuhan market, yakni terkait biaya, coverage, dan pelayanan jasa yang efektif dan efisien. Semua anggota berkewajiban secara bersama menjalankan pelaksanaan pertanggungan sesuai yang dimaksud dalam perjanjian ini, baik dalam spesifikasi pekerjaan dan/atau administratif maupun hal-hal lain yang berkaitan dengan pekerjaan sesuai dengan pembagian yang disepakati. Terlepas dari pembagian tanggung jawab kerja, dan/atau operasi, dan/ atau keuangan antara para pihak dalam perjanjian konsorsium ini, para pihak dari perjanjian konsorsium akan bertanggung jawab secara bersama-sama dan tanggung menanggung (tanggung-renteng) kepada siapapun mereka membuat perjanjianperjanjian untuk pelaksanaan penyerahan barang/jasa sebagaimana ditentukan di dalam kontrak.

Semuaanggotakonsorsiumbertanggungjawab menggantikerugian Tertanggung terhadap kewajiban-kewajiban, biaya-biaya dan pengeluaran-pengeluaran yang sah sesuai kelas asuransi yang terjadi sehubungan dengan operasi kapal milik Tertanggung yang timbul dari peristiwa-peristiwa yang terjadi selama periode pertanggungan. Berikut ini kewajiban-kewajiban yang menjadi tanggung jawab bersama anggota konsorsium asuransi penyingkiran kerangka kapal dalam kedudukannya sebagai Penanggung sebagaimana disebutkan di dalam Wording Policy: ${ }^{16}$

\section{Pengangkatan kerangka kapal}

Kewajiban atas biaya-biaya dan pengeluaran-pengeluaran untuk pengangkatan, pemindahan, penghancuran, pengapungan atau penandaan kerangka kapal atau kargo milik Tertanggung, peralatan atau harta benda yang berada atau dibawa di

\footnotetext{
${ }^{16}$ PT Tugu Pratama Indonesia Tbk., Loc. Cit.
} 
atas kapal tersebut namun dengan ketentuan bahwa Tertanggung diwajibkan oleh hukum untuk melakukan operasi atau menanggung biaya-biaya tersebut.

2. Tanggung jawab polusi

Biaya dari setiap tindakan yang diambil dengan wajar untuk menghindari atau meminimalkan polusi atau kerugian atau kerusakan yang diakibatkan serta tanggung jawab atas kehilangan atau kerusakan pada property yang disebabkan oleh tindakan yang dilakukan; biaya-biaya tindakan yang dikeluarkan untuk tujuan menghindari atau meminimalkan polusi atau mengakibatkan kerugian atau tanggung jawab yang timbul atas kerusakan atau kerugian property dari kegiatan tersebut; dan biaya-biaya tindakan yang dikeluarkan untuk mencegah bahaya dari 'accidental discharge' atau keluarnya minyak atau zat-zat berbahaya dari kapal Tertanggung yang dapat menyebabkan polusi.

Jika terjadi perselisihan antara Penanggung dan Tertanggung terkait tanggung jawab atau besarnya ganti rugi sebagaimana disebutkan di dalam Polis asuransi ini, maka perselisihan tersebut akan diselesaikan melalui forum perdamaian atau musyawarah oleh unit internal Penanggung yang bertugas menangani pelayanan dan penyelesaian pengaduan bagi konsumen. Perselisihan harus dibuat secara tertulis oleh pihak Tertanggung yang memuat tentang ketidaksepakatannya atas hal yang diperselisihkan. Penyelesaian perselisihan melalui cara ini dilakukan dalam jangka waktu maksimal 60 (enam puluh) hari kalender sejak adanya perselisihan. ${ }^{17}$ Jika cara penyelesaian perselisihan sebagaimana disebutkan di atas tidak mencapai kesepakatan, maka ketidaksepakatan tersebut harus dibuat secara tertulis oleh Penanggung dan Tertanggung. Selanjutnya Tertanggung dapat memilih penyelesaian sengketa di luar pengadilan atau melalui pengadilan dengan memilih salah satu klausul penyelesaian sengketa sebagaimana diatur di bawah ini: ${ }^{18}$

3. Lembaga Alternatif Penyelesaian Sengketa

Apabila memilih cara ini, maka dengan ini dinyatakan dan disepakati bahwa antara pihak Tertanggung dan Penanggung akan menyelesaikan sengketa melalui
17 ibid.
18 ibid. 
Badan Mediasi dan Arbitrase Asuransi Indonesia (BMAI) sesuai dengan peraturan dan prosedur yang ditetapkan BMAI atau melalui Lembaga Alternatif Penyelesaian Sengketa Asuransi lainya yang terdaftar di Otoritas Jasa Keuangan (OJK).

4. Pengadilan

Apabila memilih cara penyelesaian sengketa melalui pengadilan, maka dengan ini dinyatakan dan disepakati bahwa pihak Tertanggung dan Penanggung akan menyerahkan proses penyelesaian sengketa kepada Pengadilan Negeri di wilayah Republik Indonesia.

Pihak ketiga juga dapat menggugat anggota konsorsium yang telah menimbulkan kerugian bagi dirinya, dengan ketentuan haruslah ada kesalahan pada pihak konsorsium tersebut, harus pula ada hubungan kausalitas antara kesalahan dan kerugian yang ditimbulkan, serta adanya suatu perbuatan melawan hukum. Mengingat bahwa bentuk konsorsium bukan suatu badan hukum dan bukan pula suatu legal entitas yang mandiri, maka untuk dapat menggugat konsorsium tersebut harus dengan cara menggugat seluruh pihak atau anggota di dalam konsorsium tersebut yang dinyatakan di dalam satu surat gugatan. Terkecuali, apabila salah satu pihak atau anggota konsorsium tersebut terbukti secara nyata telah melakukan kesalahan secara pribadi merugikan penggugat tanpa mengikutsertakan nama konsorsium. ${ }^{19}$

Apabila konsorsium merugikan hak penggugat yang timbul dari suatu hubungan kontraktual antara pihak penggugat dan pihak konsorsium, maka penggugat dapat mengajukan gugatan wanprestasi dan wajib mencantumkan seluruh pihak di dalam kontrak. Dengan kata lain, konsorsium hanyalah istilah kerja sama bisnis. Sementara yang dapat menggugat ataupun digugat adalah suatu entitas hukum sebagai persona in judicio. Kecuali apabila konsorsium tersebut membentuk sebuah perusahaan berbadan hukum dengan mekanisme jont venture, maka badan hukum tersebut dapat digugat ataupun menggugat. ${ }^{20}$

\footnotetext{
${ }^{19}$ Hery Shietra, 'MENGGUGAT KONSORSIUM _ KONSULTAN HUKUM \& TRAINER JAKARTA_PERDATA, PIDANA, TANAH, KETENAGĀKERJAAN, \& PERUSAHAAN' (Legal Consultant Shietra \& Partners 2014) <https:/www.hukum-hukum.com/2014/08/menggugat-konsorsium.html $>$ diakses pada tanggal 21 Agustus 2018.

${ }^{20}$ ibid.
} 


\section{Kesimpulan}

Konsorsium asuransi penyingkiran kerangka kapal terdiri dari ketua yakni PT Tugu Pratama Indonesia dan anggota konsorsium yang dibentuk berdasarkan perjanjian kerja sama sebagai penanggung asuransi penyingkiran kerangka kapal (wreck removal insurance) termasuk tanggung jawab polusi. Konsorsium bukanlah badan hukum tetapi hanya sebagai bentuk kerja sama perusahaan asuransi nasional yang mengelola produk asuransi penyingkiran kerangka kapal. Tujuan dibentuknya konsorsium adalah untuk mendukung program pemerintah yaitu Kementerian Perhubungan Direktorat Jenderal Perhubungan Laut sebagai upaya mewujudkan keamanan dan keselamatan pelayaran di seluruh perairan Indonesia. Selain itu, juga bertujuan untuk mendapatkan keuntungan dari pengelolaan risiko yang dipertanggungkan oleh pihak tertanggung yakni biaya-biaya yang berkaitan dengan operasional penyingkiran kerangka kapal.

PT Tugu Pratama Indonesia berkedudukan sebagai Leader memiliki besaran (share) pertanggungan terbesar yang bertugas mengkoordinir seluruh anggota dan memiliki kewenangan untuk mewakili konsorsium di hadapan pihak ketiga maupun pengadilan. Semua anggota dianggap berwenang melakukan pengurusan (management) dengan saling bergantian dan bertanggung jawab mengelola risiko bersama-sama secara proporsional berdasarkan bagiannya masing-masing. Semua anggota konsorsium bertanggung jawab mengganti kerugian Tertanggung terhadap kewajiban-kewajiban, biaya-biaya dan pengeluaran-pengeluaran yang sah sesuai kelas asuransi yang terjadi sehubungan dengan operasi kapal milik Tertanggung yang timbul dari peristiwa-peristiwa yang terjadi selama periode pertanggungan.

\section{Daftar Bacaan}

\section{Buku}

Abdulkadir Muhammad, Hukum Asuransi Indonesia (Citra Aditya Bakti 2015). , Hukum Perusahaan Indonesia (Citra Aditya Bakti 2010). 
Agus Yudha Hernoko, Hukum Perjanjian Asas Proporsionalitas dalam Kontrak Komersial (Prenadamedia Grup 2010).

Ahmadi Miru, Hukum Kontrak dan Perancangan Kontrak (RajaGrafindo Persada 2008).

Chidir Ali, Badan Hukum (Alumni 2014).

Dina Sunyowati dan Enny Narwati, Buku Ajar Hukum Laut (Airlangga University Press 2013).

FX. Soegiyanto, Hukum Asuransi Maritim Protection \& Indemnity (P\&I) Insurance (Salemba Humanika 2009).

Irawan Soerodjo, Hukum Perjanjian dan Pertanahan: Perjanjian Build, Operate and Transfer (BOT) atas Tanah, Pengaturan, Karakteristik dan Praktik (Laksbang Pressindo 2016).

I Wayan Parthiana, Hukum Laut Internasional dan Hukum Laut Indonesia (Yrama Widya 2014).

Johannes Ibrahim, Hukum Organisasi Perusahaan Pola Kemitraan dan Badan Hukum (Refika Aditama 2006).

Mulhadi, Hukum Perusahaan: Bentuk-bentuk Badan Usaha di Indonesia (Rajawali Pers 2017). , Dasar-dasar Hukum Asuransi (Rajawali Pers 2017).

Peter Mahmud Marzuki, Penelitian Hukum: Edisi Revisi (Prenada Media 2005).

Philipus M. Hadjon, Argumentasi Hukum (Legal Argumentation/Legal Reasoning) Langkah-langkah Legal Problem Solving dan Penyusunan Legal Opinion (Gadjah Mada University Press 2005).

P.N.H. Simanjuntak, Pokok-pokok Hukum Perdata Indonesia (Djambatan 2009).

R. Ali Rido, Badan Hukum dan Kedudukan Badan Hukum Perseroan, Perkumpulan, Koperasi, Yayasan, Wakaf (Alumni 2004).

Rahmi Jened, Teori dan Kebijakan Hukum Investasi Langsung (Direct Investment) (Kencana 2016).

Rudhi Prasetya, Maatschap, Firma dan Persekutuan Komanditer (Citra Aditya Bakti 2004). 
, Perseroan Terbatas Teori dan Praktik (Sinar Grafika 2014).

Salim HS., Abdullah dan Wiwiek Wahyuningsih, Perancangan Kontrak dan Memorandum of Understanding (MoU) (Sinar Grafika 2008).

Sentosa Sembiring, Hukum Asuransi (Nuansa Aulia 2014).

Soedjono Dirdjosisworo, Hukum Perusahaan Mengenai Bentuk-bentuk Perusahaan (Badan Usaha) di Indonesia (Mandar Maju 1997).

Subekti, Hukum Perjanjian (Intermasa 1990).

Tuti Rastuti, Seluk Beluk Perusahaan dan Hukum Perusahaan (Refika Aditama 2015.

\section{Jurnal}

Iswi Hariyani, 'Kajian Hukum Restrukturisasi Asuransi Jiwa Bersama Bumiputera 1912 sebagai Perusahaan Mutual' (2017) 24 Ius Quia Iustum.

Julius Caesar Transon Simorangkir, 'Tanggung Jawab Sekutu Maatschap Terhadap Pihak ke-3 Dalam Suatu Perjanjian Konsorsium Terkait Bubarnya Maatschap atas Kehendak Para Sekutu (Kasus Perjanjian Konsorsium antara PT Agro Bintang Dharma Nusantara dengan Pemerintah Daerah Balikpapan, Bontang, Kutim dan Paser)' (2015) 9 Fiat Justisia.

Ralli Dibyaguna, 'Karakteristik dan Tanggung Jawab Bentuk Usaha Bersama Perusahaan Asuransi (Studi Kasus: Asuransi Jiwa Bersama Bumiputera 1912)' (2014) Jurnal Hukum Fakultas Hukum Universitas Indonesia.

\section{Perundang-undangan}

Burgerlijk Wetboek Wetboek van Koophandel voor Indonesie

Undang-Undang Nomor 17 Tahun 2008 tentang Pelayaran (Lembaran Negara Republik Indonesia Tahun 2008 Nomor 64, Tambahan Lembaran Negara Republik Indonesia Nomor 4849).

Undang-Undang Nomor 21 Tahun 2011 tentang Otoritas Jasa Keuangan (Lembaran Negara Republik Indonesia Tahun 2011 Nomor 111, Tambahan Lembaran Negara Republik Indonesia Nomor 5253).

Undang-Undang Nomor 40 Tahun 2014 tentang Perasuransian (Lembaran Negara Republik Indonesia Tahun 2014 Nomor 337, Tambahan Lembaran Negara 
Republik Indonesia Nomor 5618).

Peraturan Pemerintah Nomor 51 Tahun 2002 tentang Perkapalan (Lembaran Negara Republik Indonesia Tahun 2002 Nomor 95, Tambahan Lembaran Negara Republik Indonesia Nomor 4227).

Peraturan Pemerintah Nomor 5 Tahun 2010 tentang Kenavigasian (Lembaran Negara Republik Indonesia Tahun 2010 Nomor 8, Tambahan Lembaran Negara Republik Indonesia Nomor 5093).

Peraturan Menteri Perhubungan Nomor PM 71 Tahun 2013 tentang Salvage dan/ atau Pekerjaan Bawah Air.

Peraturan Menteri Perhubungan Republik Indonesia Nomor PM 33 Tahun 2016 tentang Perubahan atas Peraturan Menteri Perhubungan Nomor PM 71 Tahun 2013 tentang Salvage dan/atau Pekerjaan Bawah Air.

Peraturan Menteri Perhubungan Nomor PM 38 Tahun 2018 tentang Perubahan Kedua atas Peraturan Menteri Perhubungan Nomor PM 71 Tahun 2013 tentang Salvage dan/atau Pekerjaan Bawah Air.

Peraturan Direktur Jenderal Perhubungan Laut Nomor HK. 103/2/20/DJPL-14 tentang Tata Cara Pengenaan Sanksi Tidak Diberikan Pelayanan Operasional Kapal.

Peraturan Otoritas Jasa Keuangan Nomor 23/POJK.05/2015 tentang Produk Asuransi dan Pemasaran Produk Asuransi.

Surat Edaran Menteri Perhubungan Nomor. AL. 801/1/2 Phb 2014 tentang Kewajiban Mengasuransikan Kapal dengan Asuransi Penyingkiran Kerangka Kapal dan/atau Perlindungan Ganti Rugi.

\section{Laman}

Hery Shietra, Menggugat Konsorsium, Legal Opinion, https://www.hukum-hukum. com/2014/08/menggugat-konsorsium.html, diakses tanggal 21 Agustus 2018.

http://wriconsortium.com, diakses tanggal 17 April 2017.

http://www.hukumonline.com/berita/baca/lt510677b95aa13/bumiputera-tolak-usul-penghapusan-asuransi-mutual, diakses pada 31 Agustus 2018.

http://www.dephub.go.id/welcome/readPost/wajib-asuransi-kapal-diatas-35-gt-untuk-lindungi-pemilik-kapal?language=id, diakses tanggal 21 April 2018. 
http://keuangan.kontan.co.id/news/ojk-sosialisasi-asuransi-penyingkiran-rangka-kapal, diakses tanggal 16 September 2018.

HOW TO CITE: Nurhuda Sulaeman dan Agus Widyantoro, 'Tanggung Jawab Konsorsium Asuransi Penyingkiran Kerangka Kapal' (2018) Vol. 1 No. 2 Notaire. 